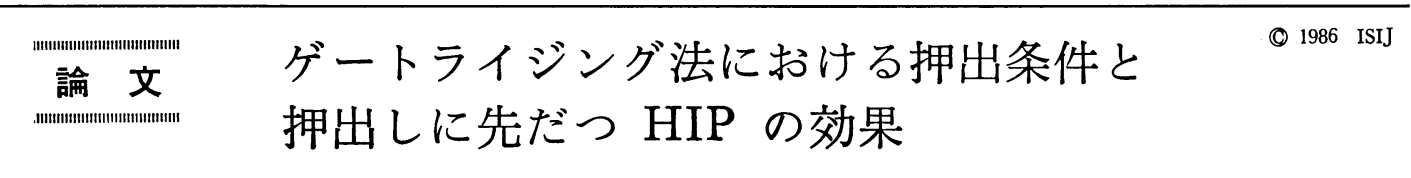

\author{
中沢 静夫* $*$ 冨塚 功 ${ }^{* 2} \cdot$ 小泉 裕* \\ 原田 広史 $*$ 山崎 道夫*2

\section{Effects of Pre-hipping and Other Extrusion Conditions in Gatorizing Process}

\begin{abstract}
Shizuo Nakazawa, Isao Tomizuka, Yutaka Koizumi,
Hiroshi HARADA and Michio YAMAZAKI
\end{abstract} \\ Effects of some processing factors in Gatorizing process were investigated for a high-W and high-Ta \\ $\mathrm{Ni}$-base superalloy. Optimum extrusion temperature to obtain extrudents suitable for superplastic forging \\ laid near but below $1200^{\circ} \mathrm{C}$, although superplastic deformation was materialized in a temperature range of \\ 1100 through $1200^{\circ} \mathrm{C}$. Hipping preceding extrusion caused lower superplasticity and narrower \\ temperature range in which superplastically forgiable extrudents were available, while it improved \\ ultimate tensile strength at $760^{\circ} \mathrm{C}$ and elongation at rupture thereby. Decrease in extrusion ratio caused \\ decrease in pressure required for extrusion, but it casued decrease in superplasticity as well as deteriration
}

Synopsis: of tensile strength at $760^{\circ} \mathrm{C}$.

\section{1.まえがき}

超耐熱合金粉末をケーシングに入れ熱間で押し出して 微細結晶組織とし，これを超塑性鍛造して所要の製品を 得る方法はゲートライジング法として知られている1). ゲートライジング法では押出しプロセスが重要なポイン トとなるが，どのような条件で押し出せば良い結果が得 られるかについてはデータが少なく2)3)，特にWや $\mathrm{Ta}$ などの含有量の多い合金については報告が見当たらな い.また，ゲートライジング法では通常はケーシングに は粉末をそのまま充填するが，粉末の代わりに粉末を HIP で固めたものを充填すれば，ヶーシングの形状上 の制約が少なくなることやケーシング内への試料の充填 密度が上昇することによつてそれなりの利点があるが， 粉末を押し出した場合と比較した例子多くない2). そこ で本報では，このような点に関する知見を得るための研 究の一部として, 一定の組成のニッケル基耐熱合金粉末 およびその HIP 材を一定の押出し比でいろいろな温度 で押し出したものについて超塑性特性とのほかの特性の 測定を行い，押出温度と HIP の影響を研究するととも に HIP 材については押出し比の影響も検討した.

\section{2. 実 験 方 法}

\section{$2 \cdot 1$ 合金及び合金インゴットからの粉末の作製} 今回の実験に使用した合金は柿販の MarM 247 合金 を上回る高温強度を有する 鋳造合金として 開発された TM-321 の炭素量を下げた合金で，著者らが TMP-7 と称しているものである. その分析組成は $\mathrm{C}: 0.07$, $\mathrm{Cr}: 7.75$, W : 12.19, Co: 8.24, Ta : 4.15, Hf: 0.80, $\mathrm{Ti}: 0.78, \mathrm{Al}: 5.06, \mathrm{~B}: 0.012, \mathrm{Zr}: 0.05$ 各重量\%, 残 $\mathrm{Ni}$ で, 本報告の著者の一部の研究による方法いによ

Table 1. Gas contents in the master ingot, powder and hipped material (ppm).

\begin{tabular}{lccc}
\hline & Master ingot & Powder & Hipped material \\
\hline $\mathrm{N}$ & 9 & 6 & - \\
$\mathrm{O}$ & 8 & 97 & 49 \\
$\mathrm{Ar}$ & - & - & $1>$ \\
\hline
\end{tabular}

Table 2. Size distribution of powder(Tyler mesh).

\begin{tabular}{ccccccccc}
\hline Mesh & +60 & +80 & +100 & +150 & +200 & +250 & +325 & Total \\
\hline wt\% & 0 & 4.15 & 9.27 & 25.58 & 47.05 & 58.11 & 78.06 & 100.0
\end{tabular}
昭和 61 年 4 月 本会講演大会にて発表 昭和 61 年 2 月 6 日受付 (Received Feb. 6, 1986)

* 金属材料技術研究所 (National Research Institute for Metals, 2-3-12 Nakameguro Meguro-ku, Tokyo 153)

*2 金属材料技術研究所 工博 (National Research Iastitute for Metals) 


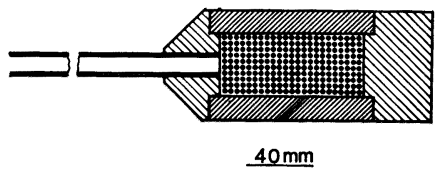

Fig. 1. Casing for powder extrusion.

つて算出した本合金の $\gamma^{\prime}$ 相の含有量は $760^{\circ} \mathrm{C}$ 付近で 65\% であつた．また，本合金のインゴット状態のガス 含有量は Table 1 のとおりであつた.

合金からの粉末の作製はアルゴンガスを使用したガス アトマイズ法で行つた．得られた合金粉は球形で，その ガス含有量と粒度分布は Table 1 と Table 2 のようで あつた。

\section{$2 \cdot 2$ HIP 処理と押出し}

HIP 処理は合金粉末を円筒に詰め, 脱気したのち $1500 \mathrm{kgf} / \mathrm{cm}^{2}$ のアルゴンガスの中に $1100^{\circ} \mathrm{G}$ で $2 \mathrm{~h}$ 保 持する方法で行つた. HIP 処理を終えた状態でのガス 含有量は Table 1 に示したとおりであつた.なお， HIP 処理の条件の 影響を検討するために $900 \mathrm{kgf} / \mathrm{cm}^{2}$, $1100^{\circ} \mathrm{C}$ で $2 \mathrm{~h}$ の HIP 処理を行つたものも 1 回の押出 し分だけ用意した。

押出し比は粉末の場合は 9.3 のみ, HIP 材の場合は, 9.3 と 5.0 とした. 粉末の押出しに使用したケーシン グの概略は Fig. 1 に示すようなもので, 図の左側に伸 びたパイプは排気のためのものである. HIP 材の場合 のケーシングはほぼ粉末用のものからパイプを欠いた形 状で, この中に長さ $80 \mathrm{~mm}$, 径 $38 \mathrm{~mm}$ に加工した HIP 材を詰めて押し出した. ケーシングの材質はすべて S35C 材もしくは同等のものである. 押出しに際しては まずガス炉で所定の温度まで加熱しその温度に $30 \mathrm{~min}$ 保持し, しかる後 400 トン・プレスを用いて押し出し た. プレスのラムの速度は $50 \mathrm{~mm} / \mathrm{s}$ で, これから計算 した押出しの所要時間は $20 \mathrm{~s}$ 以内である. 押し出され たケーシングはそのまま空気中で放冷した。なお，押出 しに使用したダイスの径は押出し比 5.0 の場合は 30.5 $\mathrm{mm}$, 押出し比 9.3 の場合は $22 \mathrm{~mm}$ であつた. なお, 特に作製した圧力 $900 \mathrm{kgf} / \mathrm{cm}^{2}$ の $\mathrm{HIP}$ 材は $1100^{\circ} \mathrm{C}$, 押出し比 5.0 でのみ押し出した.

\section{$2 \cdot 3$ 押出し材の $\mathbf{X}$ 線検查と試験}

押出し材はケーシングを付けたままでまず透過X線で 中身の検査を行い，その結果に基づいて適当と思われる 場所から押出方向と平行に超塑性特性および高温強度測 定用の試料を切り出した. 試料は平行部直径 $3 \mathrm{~mm}$ 長 さ $12 \mathrm{~mm}$ のねじつきのもので，ねじ部を除き超塑性試 験と引張試験に同形のものを使用した。なお超塑性特性

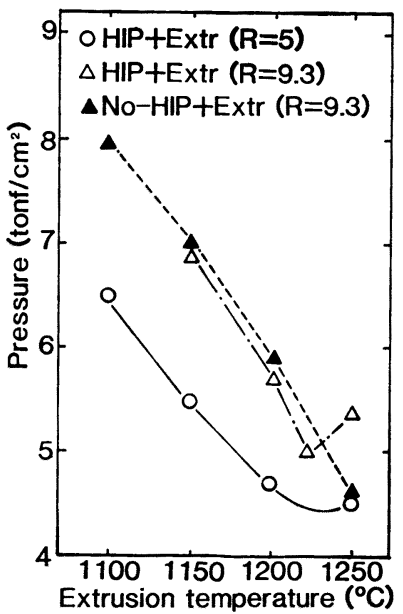

Fig. 2. Required pressure for extrusion.

の試験は Instron 型試験機を使用し，赤外線加熱装置に よつて空気中で室温から $1050^{\circ} \mathrm{G}$ まで $100^{\circ} \mathrm{C} / \mathrm{min}$ で昇 温後その温度に約 $15 \mathrm{~min}$ 保持し，それから初期ひずみ 速度 $1.05 \times 10^{-3} / \mathrm{s}$ でクロスヘッド速度が一定になるよ らにして破断まで変形を加え, その際の最大変形抵抗お よび破断までの伸びを測定する方法によつた。また，高 温引張試験は同じ装置を用いて $760^{\circ} \mathrm{C}$ まで $100^{\circ} \mathrm{C} / \mathrm{min}$ で昇温し同じく約 $15 \mathrm{~min}$ 保持したのち，クロスヘッド の速度を $0.2 \%$ 耐力までは $0.04 \mathrm{~mm} / \mathrm{min}$ ，それ以後は $1.0 \mathrm{~mm} / \mathrm{min}$ として破断まで張力を加える方法によつ た.なお，各条件での押出しは 1 回で各押出しの試験片 の数は原則として 1 本とした.

\section{3. 結果および考察}

\section{3 -1 押出しとその所要圧力}

押出し時に大きな圧力が必要になることはゲートライ ジング法の問題点の一つで, このためにゲートライジン グ法で製造できる部品の大きさが制限される.

今回の押出しは 2.3 節で述べたよらな押出し比で, 1 100-1 $250^{\circ} \mathrm{C}$ の範囲で試みたが，このうち $1100^{\circ} \mathrm{C}$ の 場合は HIP 材を比 9.3 で押し出そらとしたものは, 使用したプレスの能力の不足により押し出すことができ なかつた。 また押出し比 5.0 で押し出した HIP 圧の異 なる二つの試料のらち $1500 \mathrm{kgf} / \mathrm{cm}^{2}$ で HIP したもの は, ケーシングの中の試料が押出方向に大きく途切れ途 切れになつた。

Fig. 2 は押出しの所要圧力を示す. 図中に HIP と示 したものの値はすべて $1500 \mathrm{kgf} / \mathrm{cm}^{2}$ で HIP した場合 のもので, $900 \mathrm{kgf} / \mathrm{cm}^{2}$ で HIP したものを $1100^{\circ} \mathrm{C}$ 比 


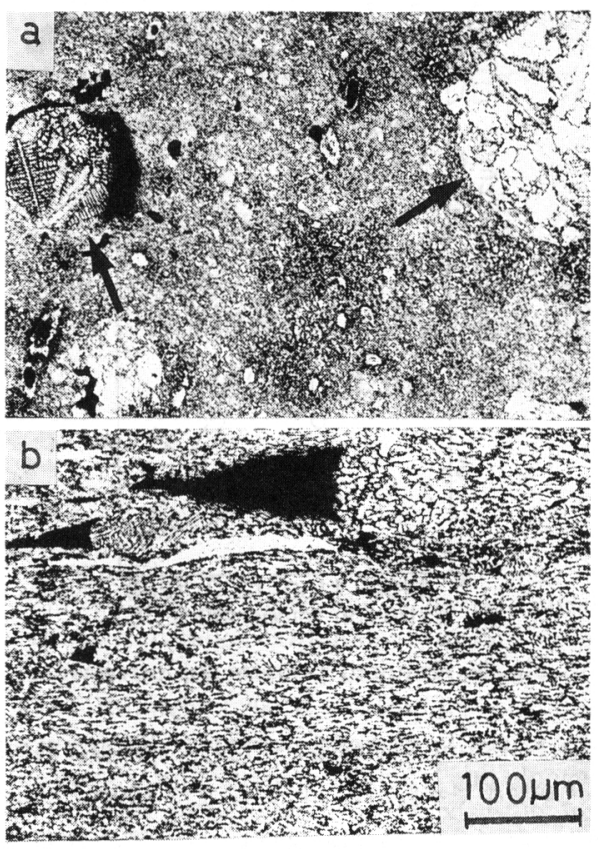

a : Longitudinal crosssection. Direction of extrusion horizontal Arrow : Hardly-crushed previous particles b : Transverse crosssection

Photo. 1. Metallurgical structures of a specimen extruded at $1100^{\circ} \mathrm{C}$ from a hipped material.

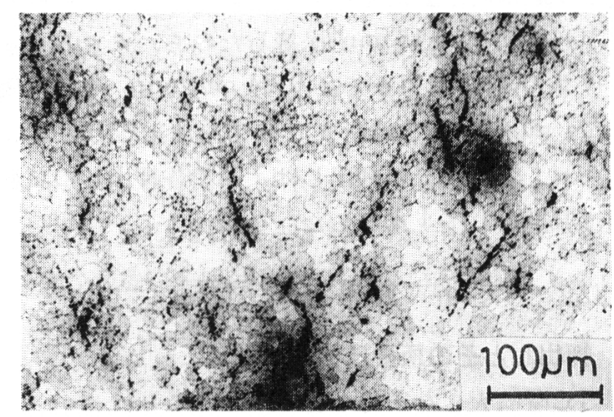

Photo.3. Cracks in the skin part of the specimen extruded at $1250^{\circ} \mathrm{C}$. At a ratio of 9.3 from hipped material, logitudinal crosssection, direction of extrusion horizontal.

5.0 で押し出した場合の值は約 $8 \mathrm{tf} / \mathrm{cm}^{2}$ であつた. 押出 温度が上昇すると押出しの所要圧力は一般には減少した が，HIP 材を比 9.3 で押し出した場合にはこれが高温 側では上昇に転じているのが認められた. 同じ押出し比 で HIP 材を押し出した場合と粉末を押し出した場合と を比較すると, 所要压力は $1150-1225^{\circ} \mathrm{C}$ の温度範囲で は大差ないが, $1100^{\circ} \mathrm{C}$ では HIP 材が押し出せなから たことや, $1250^{\circ} \mathrm{C}$ では所要の圧力が HIP 材と粉末材 とで異なつていることから，上記温度範囲外では HIP
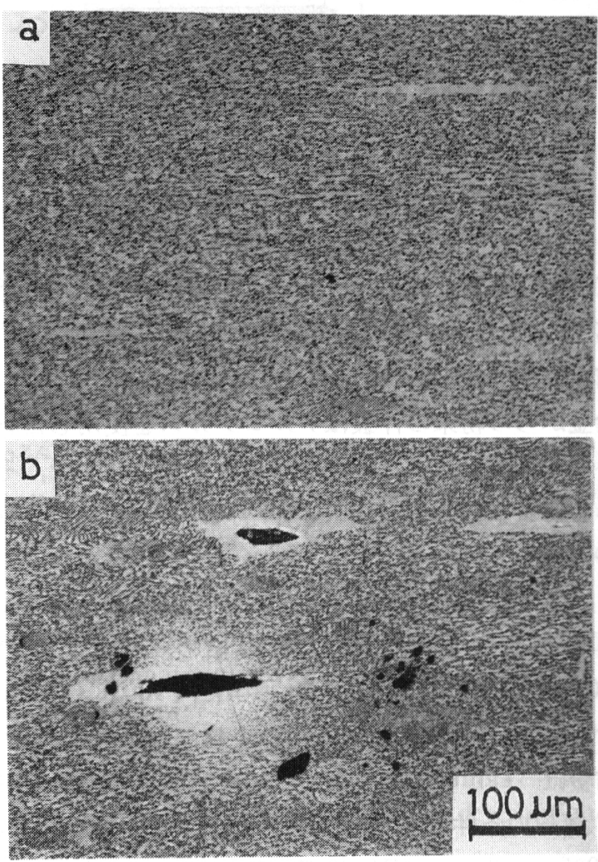

a : From hipped material b : From powder

Photo. 2. Microstructure seen in specimens extruded at $1200^{\circ} \mathrm{C}$, at a ratio of 9.3 from hipped material, longitudinal crosssection, direction of extrusion horizontal.

材の方が押し出しにくいとしてよいようである。また押 出乙比を 5.0 とした場合は所要压力は当然減少したが, その度合いは押出温度の上昇とともにある程度縮まるよ らである。な拈比 5.0 で $1100^{\circ} \mathrm{C}$ で押し出した際には HIP 圧 $900 \mathrm{kgf} / \mathrm{cm}^{2}$ のものは正常に押し出せたが, HIP 圧 $1500 \mathrm{kgf} / \mathrm{cm}^{2}$ のものは正常には押し出せなか つたことから HIP の圧力も押出しの可否に影響するよ らである。

\section{$3 \cdot 2$ 押出し材の組織と結晶の粒度}

Photo. 1 から 3 に押し出された試料の組織の例を示 す. これらの写真からわかるように押出条件は押し出さ れたものの組織に影響し, 低温で押し出されたものは組 織の均一性が低く (Photo. 1), 前 HIP の有無や押出し 比に関係なく，ボイドや Photo. 1a に矢印で示した類 の粉末があまり変化を受けずに残つているような所（以 後残留粉末部と呼ぶこととする）がかなり見受けられ た.また， $1200^{\circ} \mathrm{C}$ 付近で押し出されたものは，HIP 材 の場合はほぼ均一でボイドの少ない組織を持つていたが (Photo. 2), 粉末材の場合は多数のボイドが残つている 組織になつていた。ささら，HIP 材を $1250^{\circ} \mathrm{C}$ で押し 出した場合には, 押し出された試料のらちシース材に近 


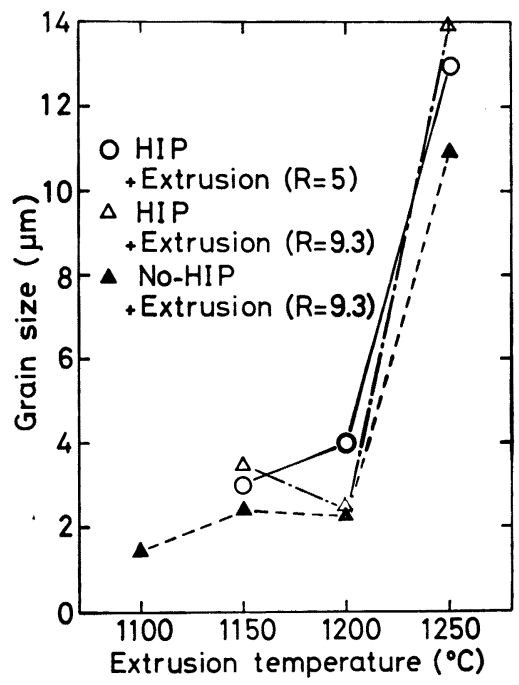

Fig. 3. Average grain sizes of the extruded specimens as determined from SEM pictures. Specimens kept at $1050^{\circ} \mathrm{C}$ for $1.5 \mathrm{~h}$ before observation.

い部分にはひび割れが見られたが (Photo. 3)，この事実 は前述の高温側で押出しに要する圧力が上昇に転ずるこ とと並んで，押出温度に上限があることを示すものであ る.

HIP 材の場合の押出し比の影響は, $1200^{\circ} \mathrm{C}$ で押し 出した際には余り顕著でないが, 低い温度では比が小さ いと均質性が若干劣るようであつた．ちなみに $900 \mathrm{kgf} /$ $\mathrm{cm}^{2}$ で HIP したものを比 5.0 で押し出した場合の試 料の組織は, $1500 \mathrm{kgf} / \mathrm{cm}^{2}$ で HIP したものの組織と は異なつていた。

押し出した試料を超塑性試験の 温度である $1050^{\circ} \mathrm{C}$ に $1.5 \mathrm{~h}$ 保つたのち, その断面の約 2 万倍の SEM 写 真を図形処理装置（ルーゼックス）にか村て算出した各 押出し材の平均結晶粒度は, Fig. 3 のようであつたに の算出に当たつては, 残留粉末部は除外して計算してあ る. 残留粉末部では通例デンドライト 組織が 残つてい た).この因に HIP 材を比 5.0 で $1100^{\circ} \mathrm{C}$ で押し出 した場合のプロットが久けているのは, この試料では結 晶粒界が粒度の測定に耐えられるほどには鮮明に観察さ れなかつたことによるものである. 図から明らかなよう に, 押出温度が $1200^{\circ} \mathrm{C}$ を超えると結晶の 粗大化が急 激に進行している。なお，一般に HIP 材の方が粒度が 若干大きくなるよらであるが，HIP 材を押し出すとき の押出し比の影響は明確でなかつた。

\section{3 超塑性変形時の态力対ひずみ曲線}

超塑性試験時の見掛けの応力は, Fig. 4 の実線のよ
らに変形の初期に急激に増大しその後一般にはしだいに 減少したが，一部の試料では末期の応力が变形量に依存 せずー定になるものもあつた，見掛けの応力が極大值後 減少する要因には本質的なるのと副次的なものとがあ り，副次的なものとしては変形にともなつて試験片の断 面積が減少すること，すなわちくびれによるものと（試 験片の平行部全体が均一にのびるとして）変形にともな つて全変形量飞対する相対的な変形速度が漸次減少する こと，すなわち真のひずみ速度の減少によるものが考光 られる。

このらち断面積の減少による分を, a . 超塑性変形が 試料片の平行部に限られ， b. 変形によつて試料の体積 が変化せずかつ，c．変形部が常に円柱形を維持して変 形するとして一次近似的な補正を行らと応力ひずみ曲線 は，一般にいくつかのステップを持つた右下がりの曲線 となつた．Fig. 4 の点線は，このような曲線(これを 便宜上補正曲線と呼ぶ）の一例で，図中にAで示した部 分がこのステップの部分である、ステップはこの図では 一つだけであるが，低い温度で変形した場合には数多く 見られ，その成因はそれが認められる時点での変形が他 の時点での変形に比較し，より一定の速度でかつより円 柱形を維持しながら進行していることによるものと考兄 ることができる，その理由は，補正曲線がな扮右下がり になる原因は，上に述べたところから本質的なものを別 とすれば，真のひずみ速度の低下によるものか，断面積 の補正が十分でなかつたことによるもの (Fig. 5 で説 明すれば，主たる変形部の径が補正に使用したaでな く，実際はbであつたことによるもの）であると考兄ら れ，これから逆にプロットの右下がりの傾向が小さくな つてステップが見られることは，これらの現象のいずれ もがあまり起きていないことを意味するからである，円 柱形の試料に引張応力を加えた際に, 変形速度が一定で から円柱形が保たれるような変形は，高分子材料の変形 では広く見られるもので，変形部が結晶化して硬化する のが原因であるとされている5 .

ステップは一般には長続きせず短寿命で終わつてしま らが，変形の末期特に変形の最終段階のステップは，か なり長く続くことがある (Fig. 4 の B 点から $\mathrm{C}$ 点ま で). いま変形に 要する応力とその応力のひずみ速度感 受性が一定である領域を均質領域と呼ぶとすると，均質 領域の大きさが一つの場所では限られていて変形の進行 とともにこれがしだいに枯渴してしまい，それまでの応 力では変形が続けられなくなつて変形部が別の離れた所 に移動してしまらのが，ステップが終わつてしまう原因 であると考觉ることができる。もし均質領域の大きさが 




Fig. 4. An example of observed stresselongation curve (ordinary line) together with its corrected version(dotted line). See text for the denotions $\mathrm{A}$, $\mathrm{B}$ and $\mathrm{C}$.
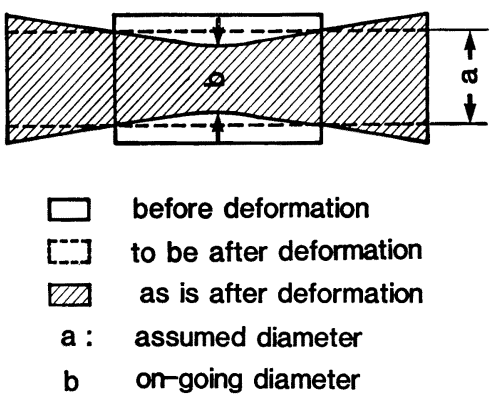

Fig. 5. Schematic crosssections of a deforming specimen. For details see text.

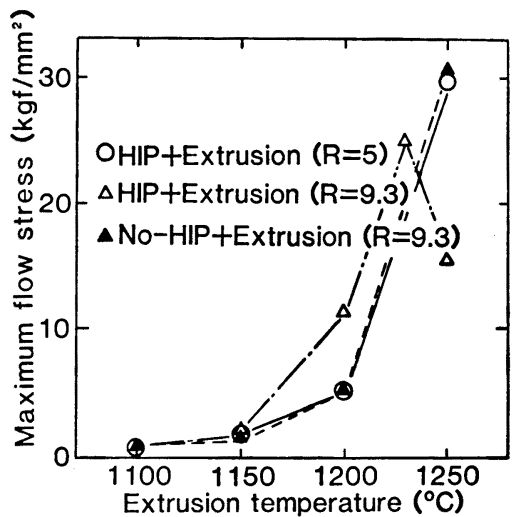

Testing temperature: $1050^{\circ} \mathrm{C}$ Deformation rate: $1.05 \times 10^{-3} / \mathrm{s}$

Fig. 6. Maximum flow stresses observed during superplastic testing.

同じとすると，その均質領域を消費してのびられるのび の長さは，変形前の径が細い場合の方が太い場合より大 きい計算となる（例えば 均質領域の体積を $v$ とすると き, 径 $4 d$ から径 $2 d$ 亿変形する際上り径 $2 d$ から径 $d$ に変形する際の方が，のびが $9 v / 4 d^{2} \pi$ だけ大きい）が， これが末期のステップが特に長続きする理由と考えられ

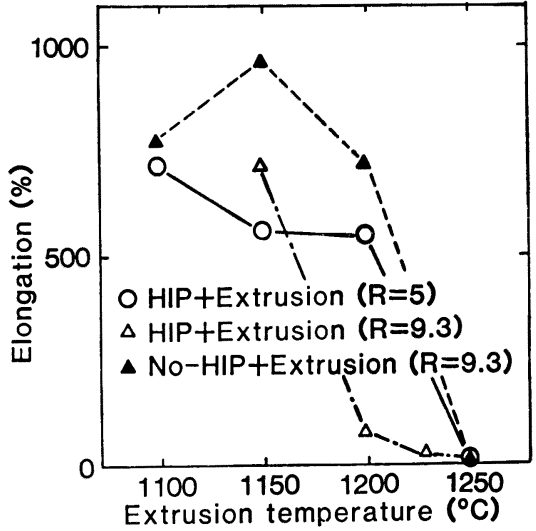

Fig. 7. Observed elongations on the superplastic testing. For testing conditions, see Fig. 6 .

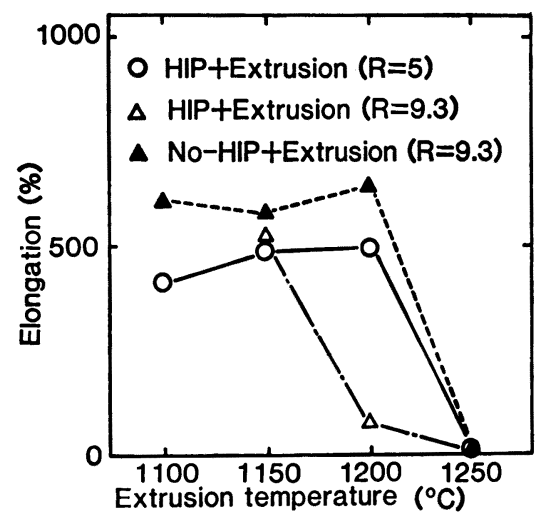

Fig. 8. "Conservatively"-estimated elongations as determined from corrected stress-strain curves. See text for its derivation.

る.

なお，補正曲線は常に右下がりであつたが，同じく右 下がりでも変形の中期以後の（伸びが 100\% 以後の）プ 


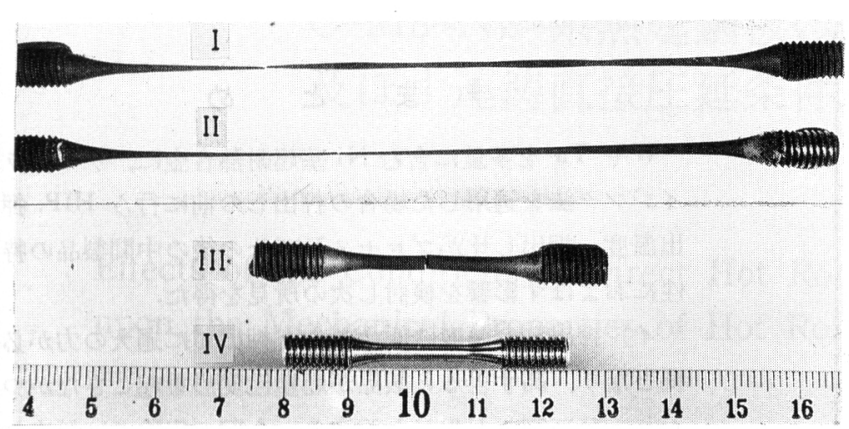

I : Example of large but nonuniform elongation Specimen : Extruded at $1100^{\circ} \mathrm{C}$ at a rate of 5.0 from hippent

II : Example of large and uniform elongation Specimen : Extruded at $1200^{\circ} \mathrm{C}$ at a ratio of 9.3 from powder

III : Example of medium elongation Specimen : Extruded at $1200^{\circ} \mathrm{C}$ at a ratio of 9.3 from hippent IV : Original test-piece

Photo. 4. Testpeieces after superplastic testing. (Scale: 1 div. $=1 \mathrm{~mm}$ ).

ロットの形が上に凸になる場合，勾配が一定の場合およ び下に凸の場合があつた. この事実は低温で押し出した ものは均質領域の規模が小さく, その力学的特性も多様 で, のびの進行に伴つて径が急速に減少することを暗示 するものであり，これは超塑性試験後の試験片の形状の 観察結果 (Photo. 4) によく対応した.

\section{4 超塑性変形時の最大変形応力と変形量}

超塑性変形応力の最大值（これは超塑性試験の極く初 期に現れるため, 事実上は超塑性変形の開始のための応 力である) は, Fig. 6 に示すよらに, 比 9.3 で HIP 材 を押し出した場合を除いてはほぼ同一の挙動を示した.

破断までの伸びいわゆる超塑性伸びの実測值は, Fig. 7 のとおりであるが，これは上で述べた最後のステッ プ, すなわち変形の終期に見られる一定の応力の下で, 試料の極く一部が大きくのびた分まで加えた值である. このような伸びの值は伸びの実測值という意味では正確 なものではあるが，その材料全体の超塑性加工の難易性 を示しているものとは考它にくい，そこでこれに代わる 材料全体の超塑性加工能の指標として, 補正曲線の勾配 のある部分を延長した点 (Fig. 4 でい光ばB点) ののび を用いることを試みた所，その変化は Fig. 8 のようで あつた、この図から見ると HIP 材を比 9.3 で $1200^{\circ} \mathrm{C}$ で押し出した場合を別とすれば, 変形量は $1100-1200^{\circ} \mathrm{C}$ の押出温度の範囲では, HIP 材粉末ともほぼ $500 \%$ と 推定され，粉末を押し出した方が HIP 材を押し出した 時より大きくなるようであつた。

このような超塑性変形挙動を Fig. 3 の平均結晶粒度 と比較することにより，次のような所見を得ることがで きる。

イ）この合金の超塑性変形が可能な素材を得るための 最適押出温度は，IN 100 などより高い6).これはこの 合金の $\gamma^{\prime}$ 相の 完全溶体化の 温度が高く（押出乙 前の HIP 材で測定した結果では, $1250^{\circ} \mathrm{C}$ と $1300^{\circ} \mathrm{C}$ の間 であつた）高温で押し出しても，結晶粒が成長しないこ
とによると思われる。

口）結晶粒度が大きくなると，超塑性変形を示さない ことはよく知られているが，今回の試料ではこれが 10 $\mu \mathrm{m}$ 程度であつた.

八）ボイドの存在や残留粉末部は，超塑性変形の大き な妨げにならない。これは，たとえボイドや残留粉末部 によつて応力集中が起き，加工硬化したとしてもその加 工硬化自身によつて, 変形場所が別の所に移つてしまい 直ちに試料の破壊に結びつかないためとして理解するこ とができる。

二) $1200^{\circ} \mathrm{C}$ で HIP 材を比 9.3 で押し出した場合の 効果から明らかなように, 結晶粒が細かいにもかかわら ず超塑性特性が良くないことがある.Fig. 3 から試験 中にこの試料だけが急速に結晶成長することはないこと が確認されているので，この原因としては，A．結晶粒 界が特殊な構造になつていて粒界滑りが起きにくい. B．超塑性変形時には，（塑性的であれ粒界移動であれ） 結晶自体の変形も必要でこのよらな変形が，この合金で は特に起きにくいの二つが候補として挙げられる．A． については，七レーションなど特別な構造は見いだされ なかつたが，この試料は前述のように，他の試料よりボ イドの量が少ないことから，これが原因である可能性も ある、ボイドがあるととれだけ自由な空間が増光, 超塑 性変形時の結晶粒の移動がそれだけスムースにいくと考 えられるからである、また，超塑性変形に粒界滑りだけ ではなく，結晶粒自体の变形も関与していることを示す 写真も報告されているので7， B．の可能性も否定でき ない。この試料の結晶粒が超塑性変形試験温度でも, 他 の試料より変形に大きな力を必要とするであろらこと は, 後に述べる $760^{\circ} \mathrm{C}$ での引張試験の結果から十分予 測できることである.

\section{3 .5 高温引張試験}

高温引張り，すなわち $760^{\circ} \mathbf{C}$ で高速で変形させた場 合の, 強度（極限抗張力）扩よび破断のびと押出条件と 


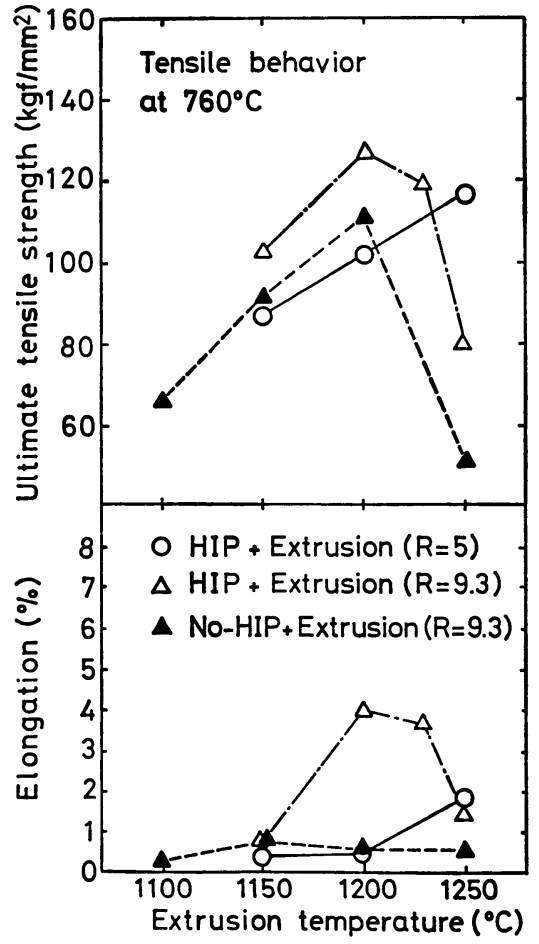

Fig. 9. Tensile strengths and elongations at $760^{\circ} \mathrm{C}$.

の関係は，超塑性変形，すなわち $1050^{\circ} \mathrm{C}$ で緩慢に変 形させた場合とは異なり，Fig. 9 飞示したと㥂りであ つた.

この図では次の 3 点が注目される.

イ）強度は，押出温度ともにまず增加し，極大を経て 低下する。

口）同じ押出し比では，HIP 材を押し出したときの 方が粉末材を押し出したときより，強度・のびとも大き くなる.

八）押出し比を小さくすると曲線が高温側にずれる. このうちイ）については, 強度の向上は溶体化温度の上 昇にともなら $\gamma^{\prime}$ 相の分散の微細化，その後の強度の低 下は結晶の疎大化による押出し時の欠陥によると理解寸 ることができるままた，口）については HIP 材の方が ボイドなどの久宿が少ないのに加えて，HIP 過程中に 既に金属粉末の大部分は潰れてしまうことから，HIP 材 の方が転位を多くトラップしているためと考兄ることが できる，八）については，押出し時には試料の実際の温 度は，名目的な押出温度より高くなるものと想像される が，押出し比が小さいと押出圧力が低くなることから推 定されるように，この温度の上昇が少なくなるためでは
ないかと推定される。

\section{4. と め}

$\mathrm{W}$ や $\mathrm{Ta}$ を多量に含む $\mathrm{Ni}$ 基超耐熱合金に, ゲートラ イジング法を適用した場合の押出しの前に行ら HIP，押 出温度，押出し比がプロセス及びその後の中間製品の特 性におよぼす影響を検討し次の所見を得た。

イ）押出しの温度は低すぎると押出しに過大の力が必 要となり，高すぎると製品が超塑性変形を起こさなかつ たり，ひび割れが生じたりする．今回の実験では粉末の 場合は押出しが可能でかつ超塑性を示す製品が得られる 温度の範囲は $1100-1200^{\circ} \mathrm{C}$ の間約 $100^{\circ} \mathrm{C}$ であつた が，低温で押し出したものは超塑性特性が十分に均一で なかつた。

口）押出しの前に HIP を行らと押出しに必要な応力 には大差がなく， $760^{\circ} \mathrm{C}$ での高温引張特性が改善された が，超塑性伸びが低下し，超塑性加工が可能な押出し材 が得られる押出温度の範囲が狭くなつた。

八）HIPをしてから押し出した場合，押出し比を下 げると押出しに必要な応力は低下したが，得られた押出 し材の超塑性および機械的特性も低下した。

この研究の遂行に当たりましては（株）神戸製鋼所の 関係者の方々にお世話になりました。 また，結晶粒径の 測定は金属材料技術研究所の松島博士の好意によるもの です.ここに記して感謝のしるしとします。

なお，この研究は通商産業省工業技術院の次世代産業 基盤技術研究開発制度に 基づき，「高性能結晶制御合金 の研究開発」の一環として行われたものである.

\section{文献}

1) V. A. Tracey and C. P. Gutler: Powder Metall. (1981) 1, p.32

2 ) C. H. Gessinger: Powder Metallugy of Superalloys, London(1984), p.77 [Butterworth]

3 ) L. N. Moskowitz, R. M. Pelloux and $N . J$. Grant: Superalloys-Processing, Proceedings of the Second International Conference (1972), Z-1 [Metals and Ceramics Information Center]

4 ）原田広史，山崎道夫：鉄と鋼，65 (1979), p. 1059

5 ) 高分子実験学 10一力学的性質 II-(高分子学会高 分子実験学編集委員会編) (1983), p.323 [共立出版]

6）滝川 博：第 3 回次世代産業基盤技術シンポジウ 厶予稿集一金属・複合材料技術一(昭和 60 年 10 月 31 日， 11 月 1日), p. 199

7 ) I. I. Novikov and V.K. Portnoj: Superplastizat von Legierungen Leipzig (1985), p.70 [VEB Deutscher Verlag fur Grundstoffindustrie] 